\title{
The influence of exposure to UV $\beta$ of fluorescent light on the bone remodeling of hypoestrogenic macaca fascicularis
}

\author{
I.A. Rachman
}

\begin{abstract}
Abstrak
Pencegahan osteoporosis merupakan suatu masalah khusus yang harus dilakukan dengan peningkatan usia harapan hidup wanita. Penurunan kalsitriol dan estrogen yang mempunyai reseptor di osteoblas, menyebabkan terjadinya mineralisasi tulang (oleh kalsitriol) dan membentuk kolagen tipe I (oleh estrogen) merupakan formasi tulang yang sempurna. Pembentukan kalsitriol dengan bahan dasar utama berasal dari vitamin $D_{3}$ kulit yang dibentuk dengan bantuan paparan UV $\beta$ matahari. Saat ini dengan adanya perubahan gaya hidup, khususnya kaum wanita yang bekerja aktif dan selalu terhindar dari paparan UV $\beta$ sepanjang hari dan akan mengalami penurunan vitamin $D_{3}$ di kalsitriol dan memasuki usia menopause akan mengancam terjadinya osteoporosis dini. Pemberian paparan UVB lampu fluoresen yang panjang gelombangnya sama dengan matahari 290-320 nm, telah lama dikenal sebagai pengobatan penyakit kulit dengan harapan produksi vitamin $D_{3}$ kulit naik. Telah dilakukan paparan UV $\beta$ lampu fluoresen terhadap kulit Macaca fascicularis yang kadar estrogennya normal, estrogen mulai rendah dan estrogen mulai sangat rendah. Ternyata pada Macaca fascicularis yang dipapar UV $\beta$ didapat kenaikan osteokalsin dan DPD tetap, yang berarti remodeling tulang tetap. Sedangkan pada Macaca fascicularis yang tidak dipapar UV $\beta$ baik yang kadar estrogen normal, mulai rendah maupun sangat rendah ditemukan penurunan kadar osteokalsin dan tetapnya kadar DPD yang berarti terjadi perubahan remodeling tulang kearah resorpsi tulang. (Med J Indones 2001; 10:63-8)
\end{abstract}

\begin{abstract}
The prevention of osteoporosis is a specific problem that should be dealt with by increasing the women's life expectation. The decrease of calcitriol and estrogen levels, which have a receptor in the osteoblast, will result in bone mineralization (due to calcitriol) and the formation of type 1 collagen (due to estrogen). The formation of calcitriol with the main basic materials from vitamin $D_{3}$ is achieved with the aid of sunray UV $\beta$. The changes in the lifestyle of women, which make them now accustomed to performing indoor activities and prevent them from being exposed to UV $\beta$ all day, have resulted in the decrease of vitamin $D_{3}$ in calcitriol in women. In addition, when entering the menopausal age they will be threatened with early osteoporosis. The exposure to the UV $\beta$ of fluorescent light with the wave length identical to sun of 290-320 nm has long been known as a modality for treating skin diseases in the hope that the production of vitamin $D_{3}$ will be increased. We exposed Macaca fascicularis, whose estrogen levels were set at normal, beginning low, beginning very low levels, to UV $\beta$ of fluorescent light. It showed that the Macaca fascicularis that were exposed to $U V \beta$ experienced an increase in osteocalcin with unchanged DPD which means that bone remodeling remains unchanged. By contrast, Macaca fascicularis with normal, beginning low, and beginning very low estrogen levels which were not exposed to UVB were found to experience a decrease in osteocalcin and unchanged DPD levels. This means that a change has occurred in the bone remodeling toward bone resorption. (Med J Indones 2001; 10: 63-8)
\end{abstract}

Keywords: UVB, osteoporosis, estrogen, vitamin $D_{3,}$ calcitriol, osteocalcin, $D P D$

The exposure to UV $\beta$ of sunray stimulates the skin to form vitamin $\mathrm{D}_{3}$ as the basic material for the formation of calcitriol. ${ }^{1-4}$ Calcitriol and osteoblast have a receptor in the osteoblast which causes the osteoblast to undergo bone mineralization and type I

Department of Obstetrics and Gynecology, Faculty of Medicine University of IndonesiaDr Cipto Mangunkusumo General Hospital, Jakarta, Indonesia collagen responsible for the perfect formation of the bones. $^{5,6}$ In the tropical zones where the sunray is abundant throughout the year, women tended to avoid the heat of the sun for fearing that their skin would turn darker. In addition, they are accustomed to working all day in the buildings covered with antiUV $\beta$ glass walls. The pervasive use of air-condition system in cars has also prevented them from being exposed sufficiently to UV $\beta$ of sunray. This lifestyle has led women to experience insufficient exposure to UB $\beta$ of sunray. ${ }^{2,3}$ Moreover, it causes a decline in vitamin $\mathrm{D}$ and calcitriol and as women enter the 
premenopausal age when estrogen is starting to decline they will encounter the problem associated with the decline in the bone remodeling which will result in bone resorption and precipitate the process of bone osteoporosis. ${ }^{1,2,3}$

Fluorescent light which emanates $U V \beta$ rays (equivalent to UV $\beta$ of sunray with a wave length of $290-320 \mathrm{~nm}$ ) has long been used as a phototherapy for psoriasis by making use of vitamin $\mathrm{D}_{3}$ produced by the skin. ${ }^{6}$ Would the exposure to UVB rays from fluorescent light, apart from increasing the production of vitamin $\mathrm{D}_{3}$ by the skin, increase the calcitriol level which would activate the osteoblast and bone formation? A number of studies have suggested that combined treatment of conjugated estrogen + progesterone + calcium and weight lifting exercise may be able to increase bone mass from 11 to $22 \%$ in one year period of treatment. ${ }^{7-11}$ The experimental study on the prevention of osteoporosis in human cannot be easily performed. For this reason, we used Macaca fascicularis as a model for the present study.

The objective of this study is to evaluate the influence of the exposure to fluorescent light UV $\beta$ on bone remodeling in hypoestrogenic Macaca fascicularis in the effort for early prevention of osteoporosis.

\section{METHODS}

The study was performed in 120 female Macaca fascicularis aged 5-8 years with body weight ranging from 2.5 to $3.5 \mathrm{~kg}$. These animals were quarantined for a period of three months before undergoing treatment. After being quarantined they were randomly divided into three groups, i.e. normal estrogen group (E0), beginning low estrogen group (E1), and beginning very low estrogen group (E2). During the preparation period of one and a half month, a sham surgery (open closed laparotomy) was performed in groups $\mathrm{E} 0$ and $\mathrm{E} 1$, and an intervention of OVX (removal of both ovaries) were done in group E2. After sham surgery Depomedroxy progesterone acetate of $5 \mathrm{mg}$ was administered for group E1 every three month.

Each group was then divided into two subgroups and received the following treatment:

a. Non-UV $\beta$ exposure during a period of six months.

b. Exposure to fluorescent light UV $\beta$ at a dose of $12 . \mathrm{mJ} / \mathrm{cm}^{2}$ during four hours a day for six months.

Grouping EO ( $n=40)$, E1 ( $n=40)$, E2 $(n=40)$

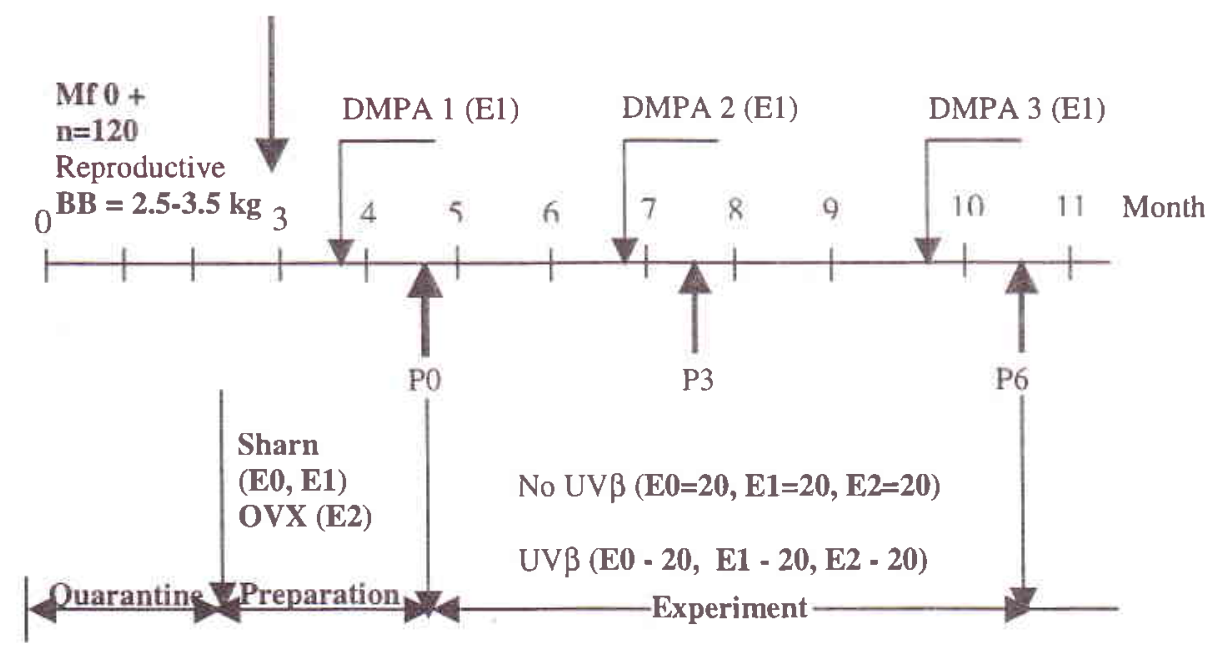

Figure 1. Study phases 
The changes in calcitriol, osteocalcin and DPD levels after three months and six months of UV $\beta$ light exposure and non-UV $\beta$ exposure were recorded (P0, P3, P6).

The fluctuation of DPD level in both UV $\beta$ exposure group and non-UV $\beta$ exposure group after three months and six months of exposure was within the normal limits. Factorial design analysis of mean variant osteocalcin (osteoblast activity) and DPD (osteoblast activity) was presented in Table 1.

Table 1. Factorial design analysis of mean variant osteocalcin level against the factors

\begin{tabular}{lrrrrl}
\hline Source & \multicolumn{1}{c}{ SS } & \multicolumn{1}{c}{ df } & MS & \multicolumn{1}{c}{ F } & P-value \\
\hline Model & 9832.51 & 17 & 578.38 & 64.95 & $0.00^{* *}$ \\
Factor 1 (E) & 339.09 & 2 & 169.54 & 13.76 & $0.00^{*}$ \\
$\begin{array}{l}\text { Estrogen group } \\
\text { Factor 2 (PR) }\end{array}$ & 3591.50 & 1 & 3591.04 & 291.55 & $0.00^{* *}$ \\
$\begin{array}{l}\text { Exposure group } \\
\text { Factor 3 (P) }\end{array}$ & 248.39 & 2 & 124.19 & 10.08 & $0.00^{* *}$ \\
$\begin{array}{l}\text { Collecting time group } \\
\text { E*PR }\end{array}$ & 364.53 & 2 & 182.27 & 14.8 & $0.00^{*}$ \\
E*P & 41.83 & 4 & 10.46 & 0.85 & 0.45 \\
PR*P & 5036.95 & 2 & 2518.47 & 204.45 & $0.00^{* *}$ \\
E*PR*P & 165.54 & 4 & 41.34 & 3.36 & $0.01^{* *}$ \\
GALAT & 3966.04 & 322 & 12.32 & & \\
\hline \multicolumn{1}{c}{ TOTAL } & 13799.04 & 399 & 40.71 & & \\
\hline
\end{tabular}

** Significant at $<0.05$ Note: $\mathrm{SS}=$ sum of squares; $\mathrm{df}=$ degree of freedom; MS

$=$ mean squares $; \mathrm{F}=\mathrm{F}=$ test $\mathrm{P}>\mathrm{f}=\mathrm{F}$ - value

Table 1 showed that there was also a significant difference between osteocalcin level and estrogen factor $(p=0.00)$, exposure factor $(p=0.00)$, and collecting time factor $(\mathrm{p}=0.00)$. There was also a significant difference $(\mathrm{p}=0.00)$ between osteocalcin level and the interaction of estrogen-exposure factor. Similarly, a significant difference $(\mathrm{p}=0.00)$ was observed in the interaction of exposure factor and collecting time factor, interaction of estrogen-exposure factor and factor-collecting time. However, no significant difference was found in the interaction of the estrogen factor and collecting time factor $(\mathrm{p}=0.4)$.

Therefore, it may be concluded that osteocalcin level was substantially influenced by estrogen factor and exposure factor, as well as collecting time factor. However, beginning low and beginning very low estrogen levels in the three experimental groups did not affect osteocalcin level.

Table 2. Factorial designs analysis of mean variant DPD level against the factors

\begin{tabular}{lrrrcc}
\hline Source & \multicolumn{1}{c}{ SS } & df & MS & F & P-value \\
\hline Model & 14.47 & 17 & 0.85 & 0.86 & 0.62 \\
Factor 1 (E) & 4.95 & 2 & 2.48 & 2.51 & 0.08 \\
$\begin{array}{l}\text { Estrogen group } \\
\text { Factor 2 (PR) }\end{array}$ & 0.23 & 1 & 0.23 & 0.23 & 0.63 \\
$\begin{array}{l}\text { Exposure group } \\
\text { Factor 3 (P) }\end{array}$ & 1.10 & 2 & 0.05 & 0.05 & 0.95 \\
Collecting time & & & & & \\
group & & & & & \\
E*PR & 1.71 & 2 & 0.85 & 0.86 & 0.92 \\
E*P & 3.66 & 4 & 0.91 & 0.92 & 0.45 \\
PR*P & 1.98 & 2 & 0.99 & 1.00 & 0.37 \\
E*PR*P & 1.59 & 4 & 0.40 & 0.40 & 0.80 \\
GALAT & 295.66 & 299 & 0.98 & & \\
\hline \multicolumn{1}{c}{ TOTAL } & 310.13 & 316 & 0.98 & & \\
\hline
\end{tabular}

Note: $\mathrm{SS}=$ sum of squares; $\mathrm{df}=$ degree of freedom; $\mathrm{MS}=$ mean squares;

$F=F=$ test $P>f=F$ - value

There was no significant relationship between mean DPD level and estrogen factor, exposure factor, and collecting time factor. UV $\beta$ light exposure increased calcitriol and osteocalcin levels in the normal estrogen level (E0), beginning low estrogen level (E1) and beginning very low estrogen level. However, DPD was still at the normal level which means that bone remodeling was still in balanced condition. In non-UV $\beta$ exposure group a decrease in calcitriol and osteocalcin levels was observed, while DPD level was still within the normal limits in the three experimental groups. This means that bone remodeling was not in balanced condition with low bone formation and normal resorption.

\section{RESULTS AND DISCUSSION}

In this study we found that hormone calcitriol level and osteocalcin level decreased to the lowest normal level in the three experimental groups after three months and six months without UV $\beta$ exposure (Figure 2 and 3). 

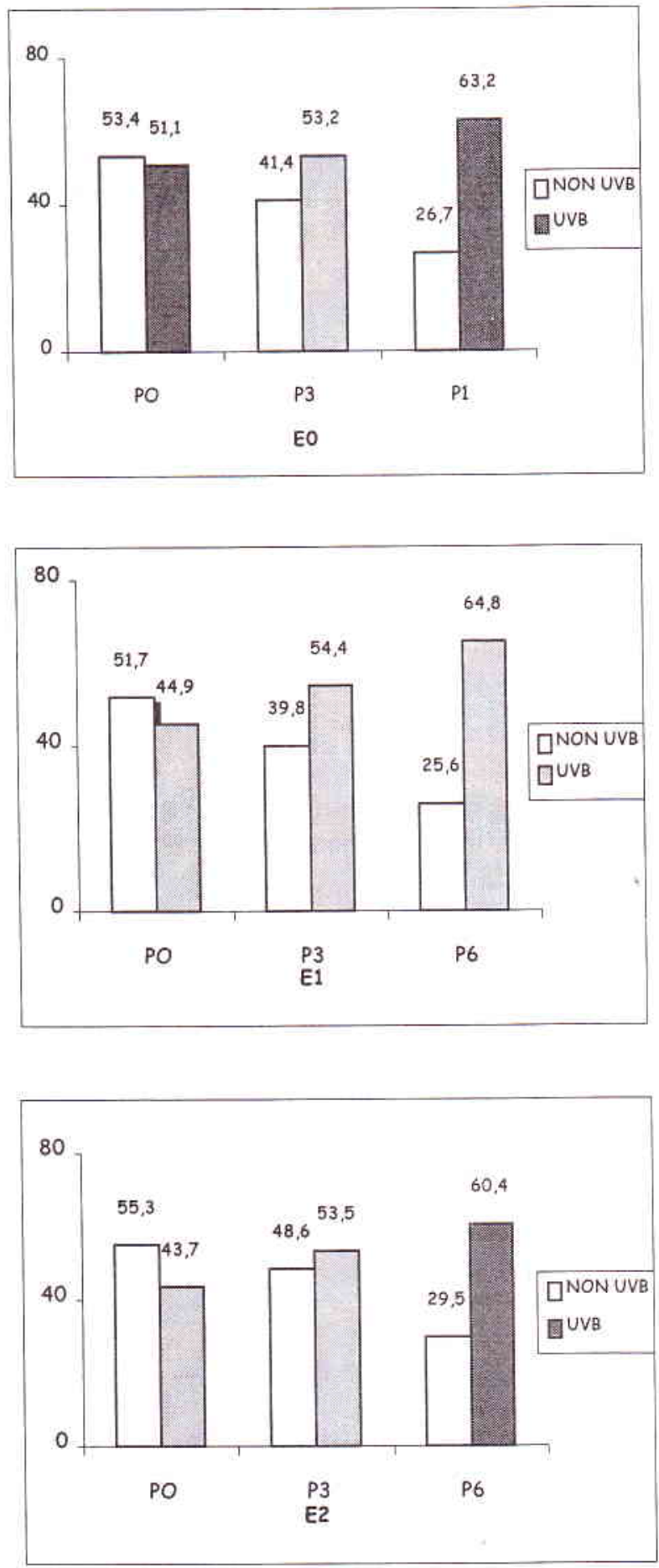

Figure 2. Mean calcitriol level in groups E0, E1, and E2 with $U V \beta$ exposure and without $U V \beta$ exposure (normal calcitriol level 43.7-75.5 ng/ml, $\square$ non-UVB exposure, $\bigotimes U V \beta$ exposure).
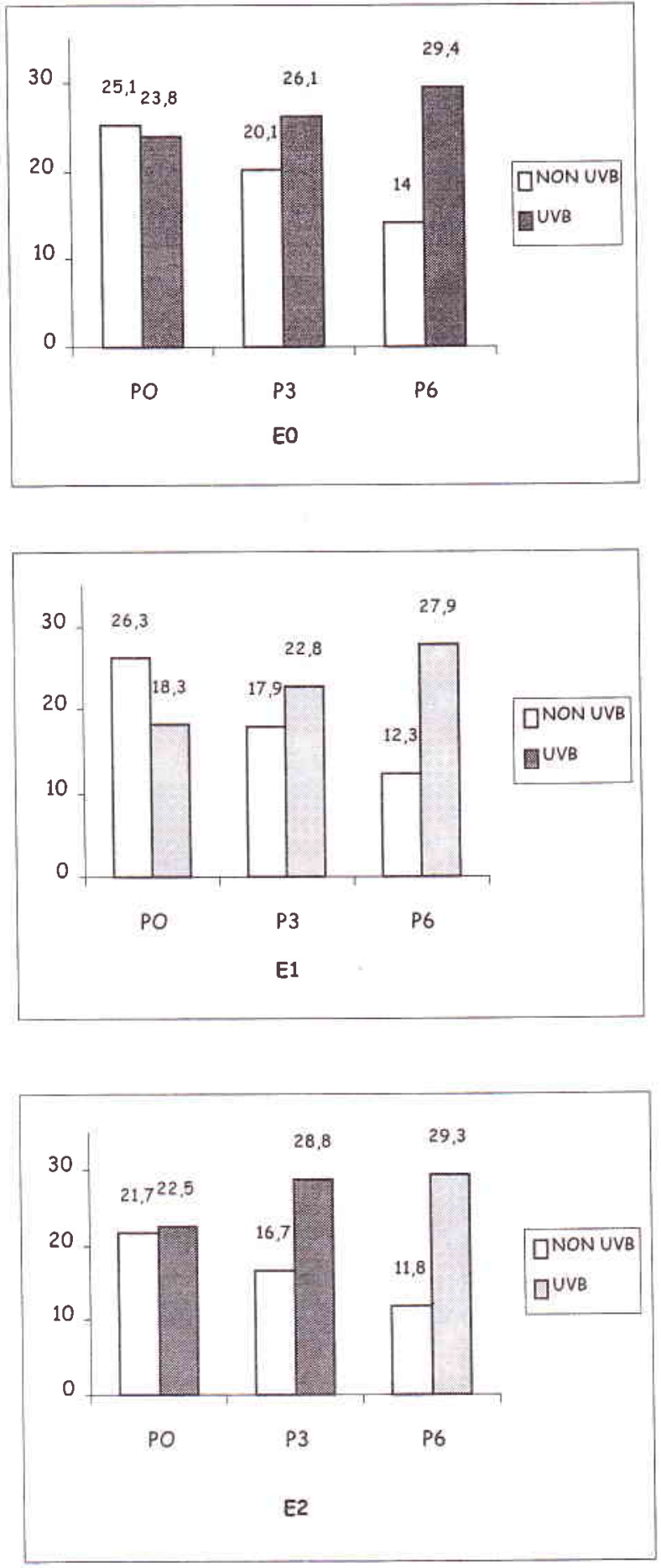

Figure 3. Mean osteocalcin level in groups E0, E1, and E2 with UV $\beta$ exposure and without UV $\beta$ exposure (normal osteocalcin level ranged from 15 to $32 \mathrm{ng} / \mathrm{ml} \square$ non- $U V \beta$ exposure, $\bigvee U V \beta$ exposure). 
An increase in calcitriol and osteocalcin levels was found in UV $\beta$ exposure group after three and six months of UV $\beta$ exposure. However, this changes was still within the normal limits in the experimental groups (Figure 2 and 3 ). It means that the activity of osteoblast in bone formation was without UV $\beta$ exposure. Nevertheless, the activity of osteoblast was still normal in UV $\beta$ exposure which means that bone formation was in normal. Regression graph of different osteocalcin level which functions at calcitriol level is presented in Figure 4.

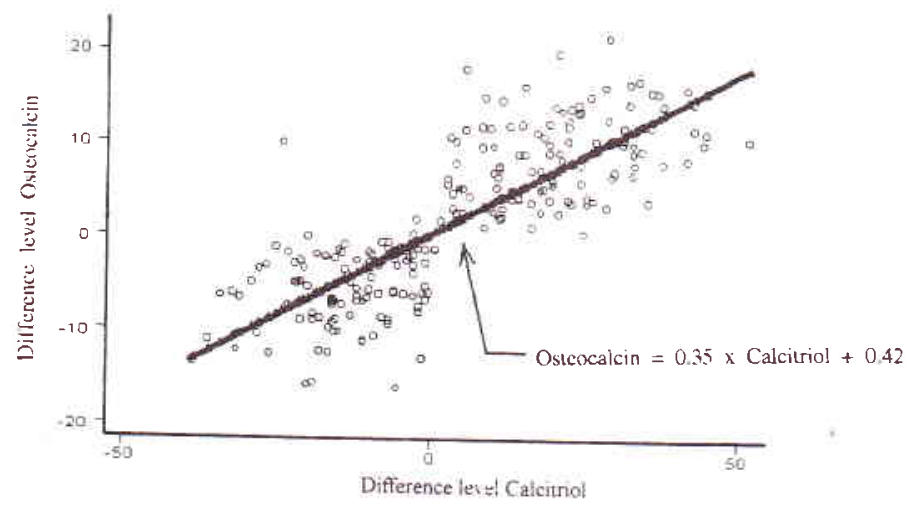

Figure 4. Regression equation graph of different calcitriol level and different osteocalcin level

The regression equation between osteocalcin level as a function of different calcitriol. level is :

$$
\text { Osteocalcin }=\mathbf{0 . 3 5} \times \text { calcitriol }+\mathbf{0 . 4 2}
$$
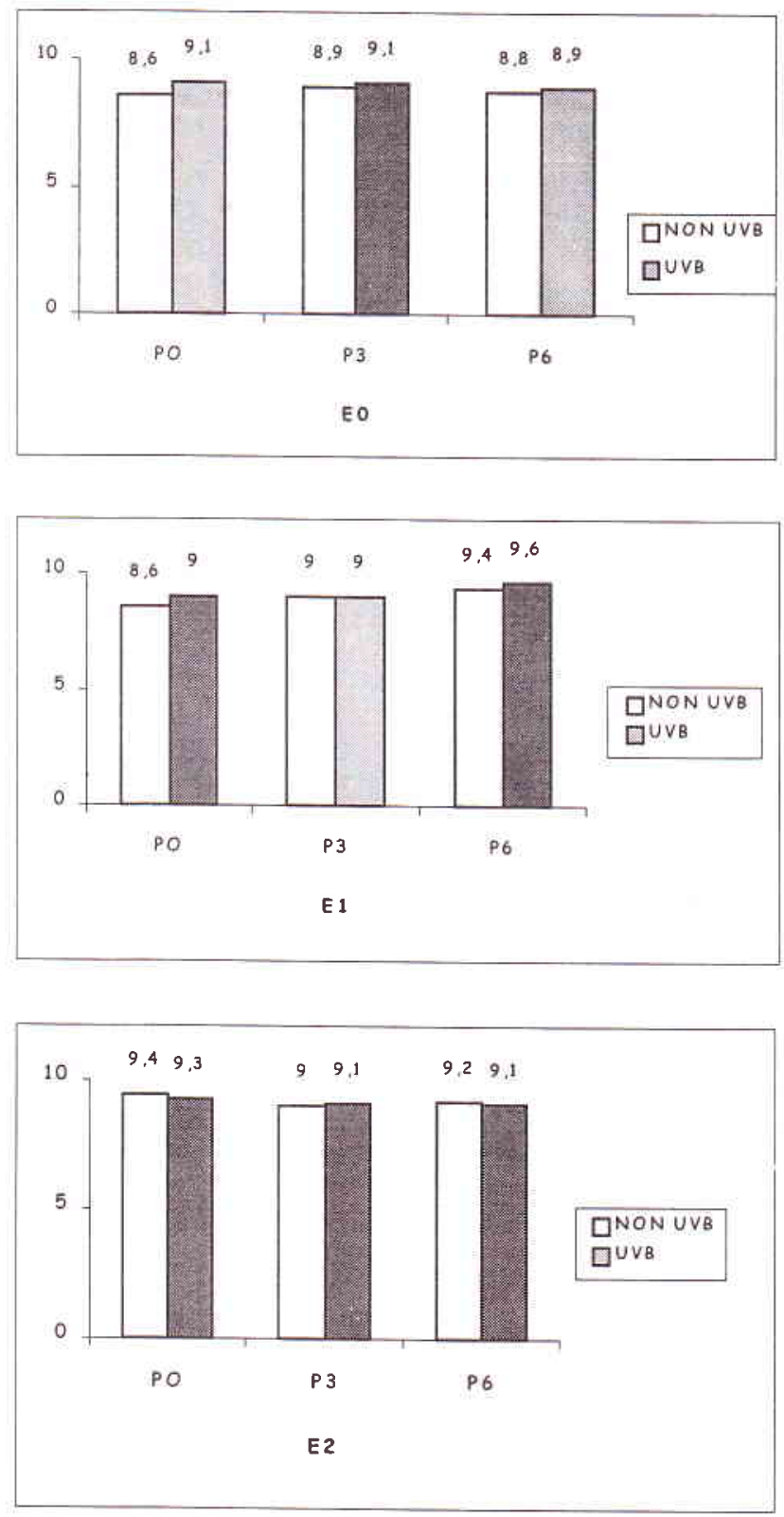

Figure 5. Mean DPD level in groups EO, E1, and E2 with and without UVB exposure (normal DPD level was 6.64-125 nM $\square$ non UV $\beta$ exposure, $\square U V \beta$ exposure) $n M$ creatinine 


\section{CONCLUSIONS}

1. Exposure to fluorescent light UV $\beta$ during the period of six months proved to maintain the equilibrium of bone remodeling (calcitriol and osteocalcin content was within the normal limits, and deoxypiridinoline content remained unchanged). An equilibrium was also maintained at normal estrogen level, beginning low and beginning very low estrogen levels.

2. Normal, beginning and beginning very low estrogen levels during the first period of three months did not affect bone formation directly. It would be best to get exposed to UV $\beta$ rays to prevent the change in bone remodeling during this period.

\section{REFERENCE}

1. Fieldman D, Molloy P, Gross C. Vitamin D, Metabolism and action. In: Markus L, Fieldman D, Kelsey J, Editor. Osteoporosis. San Diego: Academic Press Inc; 1996, $205-$ 25.

2. Holock MF, Chen TC. Vitamin $\mathrm{D}_{3}$ synthesis and biologic function in skin. Boca Raton-Florida: CRC Press Inc; 1992, 183-202.

3. Deluca HF. The vitamin D story. A Collaborative effect of basic science and clinical Medicine Faseb J; 1988;2: 224-56.

4. Subcomitte on the Tenth edition of the RDA'S, National Research Council, Recommended Dietry allowances. Washington DC: National Academic Press 1989.

5. Mongiska RJ, Rysky JT, Einhorn JA. Direct modulation of osteoblastic activity with estrogen. J Bone Joint Surg;
1994;76: 715-28.

6. Aloir JF, Vaswani A, Yeh JK, Ellis K, Yosumura S, Cohn SH. Calcitriol in the treatment of postmenopausal osteoporosis. Am J Med 1988;84: 401-8.

7. Rachman IA, Hestiantoro A, Surjana EJ, Kampono N, Helmy $\mathrm{CH}$. Comparative study between hormonal replacement therapy plus calcium and hormonal replacement therapy, calcium and vitamin $\mathrm{D}_{3}$ on the treatment in postmenopausal osteoporosis Indonesia woman. World Congress on Osteoporosis, Netherland, May 18-23, 1996.

8. Rachman IA, Hestiantoro A, Surjana EJ, Baziad A, Moeloek FA, Sumosardjuno S. Evaluation of certain clinical and laboratory changes in the treatment of postmenopausal osteoporosis between hormon replacement+ calcium and hormon replacement+calcium + vitamin $D_{3}$ and only vitamin $D_{3}$ with weight bearing exercise. Proceedings of the first Asian European Congress on the Menopause; Bangkok, Thailand 1998, 193-98.

9. Tylard WL, Speors GF, Thomsom J, Dovey S. Treatment of postmenopausal osteoporosis with calcitriol or calcium. N Engl J Med 1992;326:357-62.

10. Falch JA, Odeground OR, Finannger M, Mathesson I. Postmenopause osteoporosis: No effect of three years treatment with 1,25 dihydroxy cholecalciferol. Acta Med Scand 1987;221:199-204.

11. Gallangher JC, Riggs BL, Recker RR, Goldger D. The effect of calcitriol on patient with postmenopausal osteoporosis with special reference to fracture. Proc Soc Exp Med 1989;191-287.

12. Gallagher JC, Goldger D. Treatment of postmenopausal osteoporosis with high dose of synthetic calcitriol. A randomized controlled study, Am Intern Med 1990;113: 649-655. 